BIOMEDICAL AND BIOSOCIAL ANTHROPOLOGY
$\begin{gathered}\text { Official Journal of the International Academy } \\ \text { of Integrative Anthropology } \\ \text { journal homepage: http://bba-journal.com }\end{gathered}$

\title{
Features of organometric parameters of the palm in the perinatal period of ontogenesis
}

Guzak V. D., Slobodian O. M.

Higher State Educational Establishment of Ukraine "Bukovinian State Medical University", Chernivtsi, Ukraine

\section{ARTICLE INFO}

Received: 05 September, 2019

Accepted: 09 October, 2019

UDC: $611.976 .018-053.15 / .31$

\section{CORRESPONDING AUTHOR}

e-mail: slobodjanaleksandr@ukr.net Slobodian O. M.
Selective single data on the organometric parameters of the palm in the perinatal period of ontogenesis determines the relevance of the study. The purpose of the study is to establish the organometric parameters of the palm during the fetal and early neonatal periods of human ontogenesis. The study of the palm was performed on 51 preparations of fetal corpses (from 4 to 10 months) and 10 newborns using adequate anatomical methods: macropreparation, radiography, topographic and anatomical sections, morphometry, statistical analysis. It was found that the right hand in the perinatal period of ontogenesis is characterized by its elbow shape (54\%), for the left hand - radial (71\%). The parameters of the length of the right palm are greater than the parameters of the length of the left palm in the second trimester of fetal development and in the neonatal period; in the third trimester of fetal development the length of the left palm is greater than the length of the right. The parameters of the width of the right palm exceed these parameters of the left palm during the entire perinatal period of ontogenesis. During the perinatal period of ontogenesis the organometric parameters of the palm are characterized by two periods of accelerated development and a period of relatively slow development. For the length and width of the right and left palms, periods of accelerated development from the 4th to the 5th month of fetal development and from the 7th month to the neonatal period; from the 5th to the 7th month of fetal development - a period of relatively slow development. Models for predicting the normative values of organometric parameters of the palm during the perinatal period of ontogenesis are: palm length $=\beta_{0}+0.042 \times$ crown-heel length of the fetus, where $\beta_{0}$ : 3.587 , if the age period = 4 months; $5.562=5$ months; $4.071=6$ months; $4.840=7$ months; $6.881=8$ months; $5.624=9$ months; $5.448=10$ months; $5.765=$ newborns; palm width $=\beta_{0}+0.038 \times$ crown-heel length of the fetus, where $\beta: 2.887$, if age period $=4$ months; $4.341=5$ months; $2.638=6$ months; $3.324=7$ months; $3.548=8$ months; $1.714=9$ months; $1.814=10$ months; $3.231=$ newborns.

Keywords: palm, anatomy, morphometry, fetuses, newborns.

\section{Introduction}

Unlike the anatomy of the lower extremity, in which the principle of connecting the individual parts, strengthening their connections, each component of the hand seeks to become free, each joint tries to get rid of its shackles, and each link - to get an individual sharpened shape. In the process of evolution of the three parts of the hand (shoulder, forearm and hand), its final (distal) part - the hand - acquired special significance. It becomes not only an executor of the will, but also a creator, an educator of the brain. It should also be noted that the human hand serves not only as a tool for physical manipulation, but also as an organ of cognition and communication. The human hand, as a complex formation of bones, ligaments, muscles, blood vessels and nerves, work in harmony to perform various and complex movements [1, 2, 10, 11, 15].

Information about the individual anatomical variability of the palm depending on the sex and age is necessary to develop optimal tactics of surgical interventions on it $[4,6$, $7,14,19]$. The newborn's palms have certain features and different organometric parameters compared to adults [8, 20]. Unfortunately, in the modern scientific literature there is only selective single information about the organometric parameters of the palm in the perinatal period of ontogenesis $[3,16]$.

The purpose of the study is to establish the organometric parameters of the palm during the fetal and early neonatal 
periods of human ontogenesis.

\section{Materials and methods}

The study was performed on 51 preparations of fetal corpses (4 to 10 months) and 10 newborns of both sexes who died of causes not related to diseases of the musculoskeletal system and without external signs of anatomical abnormalities or anomalies and without obvious macroscopic abnormalities structure of the upper extremities. Adequate anatomical methods were used during the study: macropreparation, radiography, topographic anatomical sections, morphometry, statistical analysis [9].

Both fresh and fixed corpses of fetuses and newborns were used for macropreparation. The crown-heel length $(\mathrm{CHL})$ of the fetus was measured before the study. In addition, the study involved some preparations of the upper extremity from the fund of the Department of Anatomy, Clinical Anatomy and Operative Surgery of the Higher Education Institution of Ukraine "Bukovynian State Medical University". Before the morphometric examination, each hand preparation was fixed on the polyfoam with hairpins. All measurements were performed using a centimeter tape and a compass rod.

For our studies, we used the following points of the hand: A (proximal point of the palm) - the middle of the distance between the elbow and radial surfaces of the wrist on the skin fold (the border between the wrist and the front surface of the forearm); B (end point of the palm) - the place of skin connection of III-IV fingers (the most distal part of the superficial transverse metacarpal ligament between III-IV fingers); G (middle point of the palm) - the most protruding part of the rise of the thumb along the line that runs along the border between the palm and the back of the hand; $D$ (lateral point of the palm) - the thumb in pronation, the base of the first finger, which passes to the radial surface of the palm. The distance between points $A$ and $B$ determines the length of the palm, the distance between $G$ and $D$ points - the width of the palm (Fig. 1).

Statistical analysis of the obtained data was performed using a licensed program RStudio. The null hypothesis that the samples were taken from the same distribution or from distributions with the same medians was tested:

$\mathrm{H}_{0}$ : :each group has the same distribution\},

$\mathrm{H}_{1}$ : \{each group does not have the same distribution\}.

We used the Student's test, the non-parametric KruskalWallis test (answers the question of whether there is a difference between group distributions, but does not specify which groups differ), the Conover-Iman test to compare stochastic dominance and to obtain results between different pairwise comparisons after the Kruskal-Wallis test for stochastic dominance among $k$ groups. When analyzing the sample correlation coefficient $(r)$, the correlation strength was evaluated on the Chaddock scale: at $r=0$ - no correlation; at $r=$ from 0.1 to 0.3 - weak correlation; $0.3-0.5$ moderate force correlation; 0.5-0.7 - noticeable correlation;

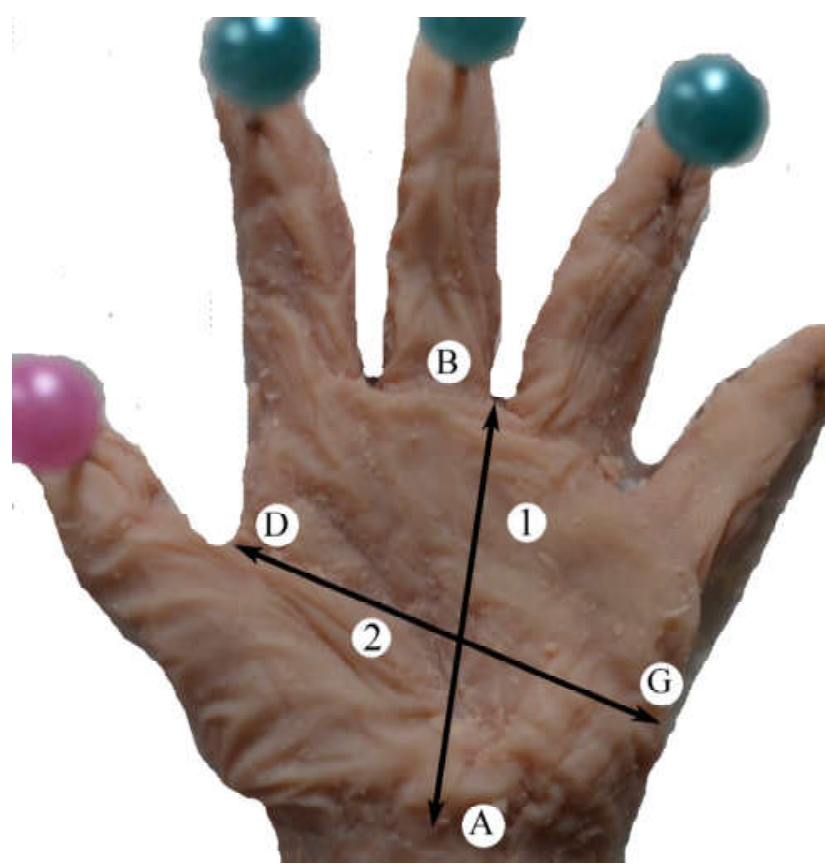

Fig. 1. The left hand of the fetus $280.0 \mathrm{~mm} \mathrm{CHL}$. Macropreparation. Mag. x2,6. 1 - palm length; 2 - palm width.

0.7-0.9 - high power correlation, 0.9-1 - very high-power correlation. The values at $p<0.05$ were considered statistically significant.

The work was performed in compliance with the main provisions of the Helsinki Declaration of the World Medical Association on ethical principles of scientific medical research with human participation (1964-2000) and the order of the Ministry of Health of Ukraine № 690 from 23.09.2009 and is a fragment of comprehensive planned initiative research work of departments M. G. Turkevich Human Anatomy, Anatomy, Clinical Anatomy and Operative Surgery of Bukovynian State Medical University (Chernivtsi, Ukraine): "Regularities of sex-age structure and topographic-anatomical transformations of organs and structures of the organism at pre- and postnatal stages of ontogenesis. Features of perinatal anatomy and embryotopography" (supervisor - Prof. O. M. Slobodyan).

\section{Results}

It is established that in the perinatal period of ontogenesis the shape of the hand is determined by two forms depending on the length of the second and fourth fingers: elbow and radial. In the second trimester of fetal development for the right and left hand is characterized by a radial form, which occurs in $60 \%$ and $82 \%$ of cases, respectively, and the rest ( $40 \%$ and $18 \%$ ) elbow. In the third trimester of fetal development, the elbow shape of the right hand is observed in $68 \%$, on the left hand - in $40 \%$ of cases. The radial shape of the hand is found in $32 \%$ on the right, on the left - in $60 \%$ (Table 1).

During the perinatal period of ontogenesis, the length of the right palm increases from $11.70 \pm 0.31 \mathrm{~mm}$ (4-month- 
Table 1. Forms of hand in the perinatal period of ontogenesis.

\begin{tabular}{|c|c|c|c|c|}
\hline \multirow{2}{*}{$\begin{array}{c}\text { Forms of } \\
\text { hand }\end{array}$} & \multicolumn{2}{|c|}{$\begin{array}{c}\text { The second trimester } \\
\text { of fetal development }\end{array}$} & \multicolumn{2}{|c|}{$\begin{array}{c}\text { The third trimester of fetal } \\
\text { development and the neonatal } \\
\text { period }\end{array}$} \\
\cline { 2 - 5 } & right hand & left hand & right hand & left hand \\
\hline Elbow & $40 \%$ & $18 \%$ & $68 \%$ & $40 \%$ \\
\hline Radial & $60 \%$ & $82 \%$ & $32 \%$ & $60 \%$ \\
\hline
\end{tabular}

Table 2. Palm length during the perinatal period of ontogenesis (mm).

\begin{tabular}{|c|c|c|c|c|}
\hline \multirow{2}{*}{ Age group } & \multicolumn{4}{|c|}{ The length of the palm } \\
\cline { 2 - 5 } & \multicolumn{2}{|c|}{ right palm } & \multicolumn{2}{c|}{ left palm } \\
\cline { 2 - 5 } & $\mathrm{M} \pm \mathrm{m}$ & $\begin{array}{c}\text { confidence } \\
\text { intervals }\end{array}$ & $\mathrm{M} \pm \mathrm{m}$ & $\begin{array}{c}\text { confidence } \\
\text { intervals }\end{array}$ \\
\hline 4 months & $11.70 \pm 0.31$ & $10.95-12.45$ & $11.47 \pm 0.39$ & $10.49-12.43$ \\
\hline 5 months & $15.51 \pm 0.91$ & $13.27-17.75$ & $15.43 \pm 0.67$ & $13.90-17.16$ \\
\hline 6 months & $16.05 \pm 0.28$ & $15.39-16.71$ & $16.04 \pm 0.42$ & $15.04-17.04$ \\
\hline 7 months & $18.54 \pm 0.49$ & $17.41-19.67$ & $18.78 \pm 0.70$ & $17.15-20.41$ \\
\hline 8 months & $22.76 \pm 0.50$ & $21.55-23.97$ & $22.97 \pm 0.73$ & $21.19-24.75$ \\
\hline 9 months & $23.72 \pm 0.56$ & $22.29-25.15$ & $23.77 \pm 0.37$ & $22.81-24.73$ \\
\hline 10 months & $25.61 \pm 0.38$ & $24.67-26.55$ & $25.54 \pm 0.49$ & $24.34-26.74$ \\
\hline Newborns & $27.10 \pm 0.76$ & $25.38-28.82$ & $26.81 \pm 0.54$ & $25.59-28.03$ \\
\hline
\end{tabular}

Table 3. Palm width during the perinatal period of ontogenesis (mm).

\begin{tabular}{|c|c|c|c|c|}
\hline \multirow{2}{*}{ Age group } & \multicolumn{4}{|c|}{ The width of the palm } \\
\cline { 2 - 5 } & \multicolumn{2}{|c|}{ right palm } & \multicolumn{2}{c|}{ left palm } \\
\cline { 2 - 5 } & $\mathrm{M} \pm \mathrm{m}$ & $\begin{array}{c}\text { confidence } \\
\text { intervals }\end{array}$ & $\mathrm{M} \pm \mathrm{m}$ & $\begin{array}{c}\text { confidence } \\
\text { intervals }\end{array}$ \\
\hline 4 months & $10.36 \pm 0.37$ & $9.461-11.26$ & $9.600 \pm 0.341$ & $8.772-10.43$ \\
\hline 5 months & $13.43 \pm 0.74$ & $11.61-15.25$ & $12.93 \pm 0.71$ & $11.20-14.66$ \\
\hline 6 months & $13.41 \pm 0.38$ & $12.53-14.30$ & $13.11 \pm 0.35$ & $12.28-13.94$ \\
\hline 7 months & $15.84 \pm 0.78$ & $14.03-17.65$ & $15.33 \pm 0.67$ & $13.78-16.88$ \\
\hline 8 months & $18.00 \pm 0.82$ & $15.99-20.01$ & $17.46 \pm 0.81$ & $15.47-19.45$ \\
\hline 9 months & $18.08 \pm 0.30$ & $17.03-18.86$ & $17.50 \pm 0.14$ & $17.15-17.85$ \\
\hline 10 months & $20.00 \pm 0.46$ & $18.87-21.13$ & $19.36 \pm 0.50$ & $18.13-20.59$ \\
\hline Newborns & $22.26 \pm 0.31$ & $21.56-22.97$ & $21.81 \pm 0.37$ & $20.97-22.65$ \\
\hline
\end{tabular}

old fetuses) to $27.10 \pm 0.76 \mathrm{~mm}$ (neonatal period), the left from $11.46 \pm 0.39 \mathrm{~mm}$ to $26.81 \pm 0.54 \mathrm{~mm}$, respectively (Table 2). According to the results of the Conover-Iman test for the length of the right and left palms, the difference in medians for all possible age pairs is statistically significant, except for pairs for the right palm "8 months - 9 months" and "10 months - newborns", for the left - "5 months - 6 months" and "8 months - 9 months".

The width of the right palm in the perinatal period of ontogenesis increases from $10.36 \pm 0.37 \mathrm{~mm}$ (4-monthold fetuses) to $22.26 \pm 0.31 \mathrm{~mm}$ (neonatal period), the left from $9.600 \pm 0.341 \mathrm{~mm}$ to $21.81 \pm 0.37 \mathrm{~mm}$ (Table 3 ). According to the results of the Conover-Iman test for the width of the right and left palms, the difference in medians for all possible age pairs is statistically significant, except for pairs for the right palm "8 months - 9 months", for the left
- "5 months - 6 months" and "8 months - 9 months".

Correlation analysis between all organometric parameters of the right and left palms during the perinatal period of ontogenesis, using the Pearson correlation coefficient, found that the values of all paired correlation coefficients are positive and close to $1(>0.85)$, indicating a close strong positive correlation between all organometric parameters.

\section{Discussion}

In the perinatal period of ontogenesis, the elbow shape is characteristic of the right hand (54\%), radial - for the left hand $(71 \%)$. With the age of the fetus, the percentage of the radial shape of the right and left hands decreases compared to the elbow shape.

Analyzing organometric data of the length of the right and left palms, we can state that in the second trimester of fetal development the parameters of the length of the right palm slightly exceed the parameters of the left palm, in the third trimester of fetal development the opposite of these parameters is found. In our opinion, this can be justified by the fact that for the third trimester of fetal development and for the newborn period for the right hand is characterized by its elbow shape. Organometric parameters of the length of the right and left palms increase the most from the 4th to the 5th month of fetal development and from the 7th month to the newborn period. In the period from the 5 th to the 7 th month of fetal development, these parameters increase slightly, this period can be called a period of delayed development.

The parameters of the width of the right palm during the perinatal period of ontogenesis are always slightly larger compared to the parameters of the width of the left palm. For the width of the right and left palms is characterized two periods of accelerated development, from the 4th to the 5th month of fetal development and from the 7th month to the newborn period. From the 5th to the 7th month of fetal development, the width of the right and left palms increases slightly.

Comparing the average values of all organometric parameters of the right and left palms in all age groups, using the Wilcoxon test, we can state that all p-values are greater than the significance level $?=0.05$, which means no significant difference. Thus, based on the arithmetic mean of the right and left palms, it is possible to build models for predicting the normative values of organometric parameters of the palm during the perinatal period of ontogenesis, using the age of the fetus and its crown-heel length. Some evidence of a significant difference in mean values relative to the organometric parameters of the palm are given in the scientific works of Albay S. et al. [3], Ritterband-Rosenbaum A. et al. [16].

The model of palm length during the perinatal period of ontogenesis has the form: palm length $=\beta_{0}+0.042 \times$ crownheel length of the fetus, where $\beta_{0}=3.587$, if the age period $=4$ months; $5.562=5$ months; $4.071=6$ months; $4.840=$ 
7 months; $6.881=8$ months; $5.624=9$ months; $5.448=10$ months; $5.765=$ newborns. The coefficient of determination of the model is $94.54 \%$.

The model of palm width during the perinatal period of ontogenesis has the form: palm width $=\beta_{0}+0.038 \times$ crownheel length of the fetus, where $\beta_{0}=2.887$, if the age period $=4$ months; $4.341=5$ months; $2.638=6$ months; $3.324=$ 7 months; $3.548=8$ months; $1.714=9$ months; $1.814=10$ months; $3.231=$ newborns. The coefficient of determination of the model is $89.3 \%$.

Modifications of the structure and shapes of the upper limb, in particular the hand, demonstrate a large number of variants, the etiological basis of which are complex and numerous processes of changes in embryonic development $[5,12,13,17,18]$. Interest in the anatomical features of the hand is due to the increase in the number of medical and diagnostic procedures that require direct access to the lower structures of the palm, considering the individual typological characteristics of patients.

\section{Conclusions}

1. For the right hand in the perinatal period of ontogenesis is characterized by its elbow shape (54\%), for the left hand - radial $(71 \%)$. The parameters of the length of the right palm are greater than the parameters of the length of the left palm in the second trimester of fetal

\section{References}

[1]Akhtemiichuk, Yu. T. (2012). Relevance of scientific research in the field of perinatal anatomy. Neonatology, surgery and perinatal medicine, 2(1), 15-21.

[2] Akhtemiichuk, Yu. T., Slobodian, O. M., \& Lavriv, L. P. (2014). Prenatal development of organs and structures of the body. Experimental and clinical medicine, (3), 18-21.

[3] Albay, S., Kastamoni, Y., Sakalli, B. U. S. R. A., \& Tunali, S. (2013). Anatomy and variations of palmaris longus in fetuses. Rom J Morphol Embryol, 54(1), 85-89. PMID: 23529313

[4] Baitinger, V. F., Golubev, I. O., \& Shmatov, S. V. (2010). Clinical anatomy of the hand (part I). Reconstructive and plastic surgery issues, 4(35), 29-40.

[5] Bidarkotimath, S., Avadhani, R., \& Kumar, A. (2011). Primary pattern of arteries of upper limb with relevance to their variations. Int J Morphol, 29(4), 1422-1428. doi: 10.1055/s0040-1703547

[6] Deikalo, V. P., Tolstik, A. N., \& Boloboshko, K. B. (2013). Clinical anatomy of the hand and surgical approaches: a guide. Vitebsk: VSMU.

[7] Eskin, N. A., Pripisnova, S. G., \& Matveeva, N. Yu. (2010). Normal ultrasound anatomy of the hand. Ultrasound, (20), 1927.

[8] Gadzhieva, F. G. (2014). Individual variability of the main arteries of the upper and lower limbs of a person. Journal of Grodno State Medical University, (2), 105-108.

[9] Huzak, V. D., \& Slobodian, O. M. (2017). The method of anatomical study of the fetal palmar structures. Natural Science Readings, May 18-21; Bratislava (p. 32-33). Bratislava.

[10] Huzak, V. D., \& Slobodian, O. M. (2018). The current state of development and formation of the structure of the bones of the hand. Clinical anatomy and operative surgery, 17(4), 96102. doi: $10.24061 / 1727-0847.17 .4 .2018 .18$ development and in the neonatal period, in the third trimester of fetal development the length of the left palm is greater than the length of the right. The parameters of the width of the right palm exceed these parameters of the left palm during the entire perinatal period of ontogenesis.

2. During the perinatal period of ontogenesis, the organometric parameters of the palm are characterized by two periods of accelerated development and a period of relatively slow development. For the length and width of the right and left palms periods of accelerated development continue from the 4 th to the 5 th month of fetal development and from the 7th month to the neonatal period; from the 5th to the 7 th month of fetal development - a period of relatively slow development.

3. Models for predicting normative values of organometric parameters of the palm during the perinatal period of ontogenesis have the following form: palm length $=\beta_{0}+0.042 \times$ crown-heel length of the fetus, where $\beta_{0}=$ 3.587 , if the age period $=4$ months; $5.562=5$ months; $4.071=6$ months; $4.840=7$ months; $6.881=8$ months; $5.624=9$ months; $5.448=10$ months; $5.765=$ newborns; palm width $=\beta_{0}+0.038 \times$ crown-heel length of the fetus, where $\beta_{0}=2.887$, if the age period $=4$ months; $4.341=5$ months; $2.638=6$ months; $3.324=7$ months; $3.548=8$ months; $1.714=9$ months; $1.814=10$ months; $3.231=$ newborns.

[11] Khmara, T. V., Vasylchyshyn, Ya. M., Hresko, A. S., \& Biriuk, I. G. (2014). Ontology of congenital malformations of the skeleton of the hand. Clinical anatomy and operative surgery, 13(4), 93-99.

[12] Kume, T. (2010). Specification of arterial, venous, and lymphatic endothelial cells during embryonic development. Histology and histopathology, 25(5), 637-646. doi: 10.14670/hh-25.637

[13] Menshawi, K., Mohr, J. P., \& Gutierrez, J. (2015). A functional perspective on the embryology and anatomy of the cerebral blood supply. Journal of stroke, 17(2), 144-158. doi: 10.5853/ jos.2015.17.2.144

[14] Natsis, K., Papadopoulou, A. L., Papathanasiou, E., Noussios, G., Paraskevas, G., \& Lazaridis, N. (2020). Study of two cases of high-origin radial artery in humans. European Journal of Anatomy, 13(2), 97-103.

[15] Petrenko, V. M. (2015). Human development. Development issues in human anatomy. Moscow-Berlin: Direct Media.

[16] Ritterband?Rosenbaum, A., Herskind, A., Li, X., WillerslevOlsen, M., Olsen, M. D., Farmer, S. F., \& Nielsen, J. B. (2017). A critical period of corticomuscular and EMG-EMG coherence detection in healthy infants aged 9-25 weeks. The Journal of physiology, 595(8), 2699-2713. doi: 10.1113/JP273090

[17] Shubha, R., Sudarshan Babu, K. G., Mekala, D., Jeyanthi, K., \& Lalitha, C. (2013). An anatomical study of variations in termination of brachial artery: embryological basis and clinical implication. J. Dent. Med. Sci, 9(1), 68-75. doi: 10.9790/08530916875

[18] Singla, R. K., Sharma, R., \& Sharma, T. (2012). Superficial BrachialArtery with its High Division. Journal of the Nepal Medical Association, 52(187), 138-141.

[19] Sivakon, S. V. (2003). Influence of surgical access and volume of excision of the palmar aponeurosis on the duration and 
results of treatment for Dupuytren's contracture. Clinical medicine, (1), 24-32.

[20] Vovk, Yu. M., \& Vovk, O. Yu. (2019). Individual anatomical variability and their clinical and morphological significance. Kharkiv: FOP Bronin O. V.

\section{ОСОБЛИВОСТІ ОРГАНОМЕТРИЧНИХ ПАРАМЕТРІВ ДОЛОНІ В ПЕРИНАТАЛЬНОМУ ПЕРІОДІ ОНТОГЕНЕЗУ \\ Гузак В. Д., Слободян О. М.}

Вибіркові поодинокі відомості щодо органометричних параметрів долоні у перинатальному періоді онтогенезу визначають актуальність дослідження. Мета дослідження - встановити органометричні параметри долоні впродовж фетального та раннього неонатального періодів онтогенезу людини. Дослідження долоні проведено на 51 препараті трупів плодів (від 4 до 10 місяців) та 10 новонароджених за допомогою адекватних анатомічних методів: макропрепарування, рентгенограсрія, виготовлення топографоанатомічних зрізів, морфометрія, статистичний аналіз. Встановлено, що для правої кисті у перинатальному періоді онтогенезу характерна ліктьова ї̈ фрорма (54 \%), для лівої кисті - променева (71 \%). Параметри довжини правої долоні є більшими над параметрами довжини лівої долоні у другому триместрі внутрішньоутробного розвитку і в період новонародежності; у третьому триместрі внутрішньоутробного розвитку довжина лівої долоні $\epsilon$ більшою над довжиною правої. Параметри ширини правої долоні перевищують дані параметри лівої долоні впродовж всього перинатального періоду онтогенезу. Упродовж перинатального періоду онтогенезу для органометричних параметрів долоні характерні два періоди прискореного розвитку і період відносно сповільненого розвитку. Для довжини і ширини правої і лівої долонь періоди прискореного розвитку - з 4-го по 5-й місяці внутрішньоутробного розвитку та з 7-го місяця по період новонародженості; з 5-го по 7-й місяці внутрішньоутробного розвитку - період відносно сповільненого розвитку. Моделі прогнозування нормативних значень органометричних параметрів долоні упродовж перинатального періоду онтогенезу мають вигляд: довжина долоні $=\beta_{0}+0,042$ х тім'яно-п'яткова довжина плода, де $\beta_{0}: 3,587$, якщо віковий період $=4$ міс; 5,562 $=5$ міс; 4,071 = 6 міс; 4,840 = 7 міс; 6,881 = 8 міс; 5,624 = 9 міс; 5,448 = 10 міс; 5,765 = новонароджені; ширина долоні $=\beta_{0}+0,038$ х тім'яно-п'яткова довжина плода, де $\beta_{0}: 2,887$, якщо віковий період = 4 міс; 4,341 = 5 міс; 2,638 = 6 міс; 3,324 = 7 міс; 3,548 = 8 міс; 1,714 = 9 міс; 1,814 = 10 міс; 3,231 = новонароджені.

Ключові слова: долоня, анатомія, морфометрія, плоди, новонароджені.

\section{ОСОБЕННОСТИ ОРГАНОМЕТРИЧЕСКИХ ПАРАМЕТРОВ ЛАДОНИ В ПЕРИНАТАЛЬНОМ ПЕРИОДЕ ОНТОГЕНЕЗА} Гузак В. Д., Слободян А. Н.

Выборочные единичные сведения об органометрических параметрах ладони в перинатальном периоде онтогенеза определяют актуальность исследования. Цель исследования - установить органометрические параметры ладони в течение фетального и раннего неонатального периодов онтогенеза человека. Исследование ладони проведения на 51 препарате трупов плодов (от 4 до 10 месяцев) и 10 новорожденных с помощью адекватных анатомических методов: макропрепарирование, рентгенография, изготовление топографоонатомических срезов, морфометрия, статистический анализ. Установлено, что для правой кисти в перинатальном периоде онтогенеза характерна локтевая ее фоорма (54 \%), для левой кисти - лучевая (71\%). Параметры длины правой ладони являются большими чем параметры длины левой ладони во втором триместре внутриутробного развития и в период новорожденности, в третьем триместре внутриутробного развития длина левой ладони является большей чем длина правой. Параметры ширины правой ладони превышают данные параметры левой ладони в течение всего перинатального периода онтогенеза. В течение перинатального периода онтогенеза для органометрических параметров ладони характерны два периода ускоренного развития и период относительно замедленного развития. Для длины и ширины правой и левой ладоней периоды ускоренного развития - с 4-го по 5-й месяца внутриутробного развития и с 7-го месяца по период новорожденности; с 5-го по 7-й месяца внутриутробного развития - период относительно замедленного развития. Модели прогнозирования нормативных значений органометрических параметров ладони в течение перинатального периода онтогенеза имеют вид: длина ладони $=\beta_{0}+$ 0,042 х теменно-пяточная длина плода, где $\beta_{0}:$ 3,587, если возрастной период $=4$ мес; 5,562 = 5 мес; 4,071= 6 мес; 4,840 = 7 мес; 6,881 = 8 мес; 5,624 = 9 мес; 5,448 = 10 мес; 5,765 = новорожденные; ширина ладони = $\beta_{0}+0,038 \times$ теменно-пяточная длина плода, где $\beta_{0}: 2,887$, если возрастной период = 4 мес; 4,341 = 5 мес; 2,638 = 6 мес; 3,324 = 7 мес; 3,548 = 8 мес; 1,714 = 9 мес; 1,814 = 10 мес; 3,231 = новорожденные.

Ключевые слова: ладонь, анатомия, морфометрия, плоды, новорожденные. 